\title{
A CASA DA MADRINHA: O PROCESSO DE INDIVIDUAÇÃO NA OBRA DE LYGIA BOJUNGA
}

\author{
A Casa da Madrinha: the individuation process in Lygia Bojunga's work
}

\author{
Dalízia Amaral Cruz \\ https://orcid.org/0000-0002-0474-7537 (c) \\ Universidade Federal do Pará, Programa de Pós-Graduação em Teoria e Pesquisa do \\ Comportamento, Belém, PA, Brasil.66075-110 - secretariappgtpcufpa@gmail.com \\ Marluce Cristina Araújo Silva \\ https://orcid.org/0000-0001-9677-0840 을 \\ Universidade Federal do Pará, Programa de Pós-Graduação em Artes, Belém, \\ PA, Brasil.66060-28 - ufpa.ppgartes@gmail.com \\ Elson Ferreira Costa \\ https://orcid.org/0000-0003-4115-9029 c \\ Universidade do Estado do Pará, Curso de Terapia Ocupacional, Belém, \\ PA, Brasil.66095-661 - terapiaocupacional@uepa.br
}

Resumo: Consagrada entre os mais destacados escritores brasileiros da literatura infantojuvenil, a narrativa de Lygia Bojunga entrelaça a temática social ao conflito psicológico e ao processo de amadurecimento das personagens protagonistas. Ou seja, elementos do real servem de base para a fantasia, possibilitando várias formas de leitura das histórias criadas pela escritora. Nesse sentido, o presente artigo traz uma abordagem teórico-analítica, em que o objetivo foi analisar a obra A Casa da Madrinha, de Lygia Bojunga (2015), a partir de uma leitura junguiana. A jornada de Alexandre, personagem central, é desvelada como símbolo do processo de individuação. A Psicologia Analítica de Carl Gustav Jung (1875-1961) foi utilizada como instrumento de revelação do simbólico, do mitológico da obra da escritora, ou seja, para a interpretação do espaço de fantasia da narrativa e do processo de individuação do personagem protagonista da história. $\mathrm{Na}$ literatura de Lygia Bojunga, a imaginação não aparece como fator de alienação do real, mas como processo fundamental de transformação e mobilização da vida, onde o personagem Alexandre, na experiência de seu processo de individuação, foi capaz de ressignificar seus espaços de vida exterior e interior.

Palavras-chave: A Casa da Madrinha. Símbolo. Processo de Individuação. Psicologia Analítica. Literatura Infantojuvenil.

Abstract: Consecrated among the most outstanding brazilian writers of children's literature, Lygia Bojunga's narrative intertwines the social theme with the psychological conflict and the process of maturing of the protagonist characters. In other words, elements of the real serve as a basis for fantasy, enabling various ways of reading the stories created by the writer. In this sense, this article brings a theoretical-analytical approach, in which the 
objective was to analyze the work A Casa da Madrinha, by Lygia Bojunga (2015), from a jungian reading. Alexandre's journey, the central character, is revealed as a symbol of the individuation process. The Analytical Psychology of Carl Gustav Jung (1875-1961) was used as an instrument to reveal the symbolic, the mythological of the writer's work, that is, for the interpretation of the fantasy space of the narrative and the process of individuation of the protagonist character of the story. In Lygia Bojunga's literature, imagination does not appear as a factor of alienation from the real, but as a fundamental process of transformation and mobilization of life, where the character Alexander, in the experience of his individuation process, was able to resignify his outer and inner living spaces.

Keywords: A Casa da Madrinha. Symbol. Individuation Process. Analytical Psychology. Children's Literature.

\section{Introdução}

Nascida em Pelotas - RS em 1932, a atriz, tradutora e escritora Lygia Bojunga está entre os mais destacados escritores brasileiros da literatura infantojuvenil. No conjunto de seus livros, a construção narrativa tem como fundamento a indeterminação entre realidade e fantasia (PIRES; GOMBOEFF, 2012). Sua produção, assim, apresenta uma característica específica de trazer as temáticas sociais envoltas pela dimensão simbólica.

Nas obras de Lygia Bojunga, geralmente, a temática social é entrelaçada ao conflito psicológico e ao processo de amadurecimento dos personagens protagonistas. Nesse sentido, a narrativa da autora é impregnada de metáforas, em que elementos do real servem de base para a fantasia. Ao antropomorfizar objetos do cotidiano, a autora apresenta uma produção literária que, entre os aspectos de sua criação poética, possibilita várias leituras das histórias. Na fusão entre fantasia e realidade, Lygia Bojunga manipula artisticamente elementos do real, conferindo à sua produção excelente qualidade literária.

De acordo com Sandroni (1987), as narrativas da escritora se dividem em dois planos: o plano horizontal, no qual se desenvolvem os fatos sequenciais vividos por seus diversos personagens e o plano vertical, no qual a narrativa volta-se para o interior dos personagens. Neste último plano, a obra de Lygia Bojunga pode ser lida e interpretada de uma perspectiva psicológico-simbólica, entendendo a experiência vivida por seus protagonistas pela perspectiva da integração do ser com o mundo. É o caso da obra A Casa da Madrinha, que apresenta a história de Alexandre, um menino da periferia do Rio de Janeiro, que sai em busca da casa de sua madrinha, lugar imaginado por seu irmão, Augusto, para distrair Alexandre da fome e falta de sono.

Diante de tais considerações, o presente artigo, de abordagem teórico-analítica, teve por objetivo analisar a obra A Casa da Madrinha, a partir de uma leitura junguiana, desvelando a jornada de Alexandre, personagem central, como símbolo do processo de individuação do indivíduo. Dessa forma, a Psicologia Analítica de Carl Gustav Jung (18751961) será utilizada como instrumento de revelação do simbólico, do mitológico, na obra de Lygia Bojunga. 


\section{A Casa da Madrinha: contando um pouco da história}

Publicado em 1978, e premiado neste mesmo ano como o melhor livro para jovens pela Fundação Nacional do Livro Infantojuvenil (FNLIJ), A Casa da Madrinha é a quarta obra da escritora e conta a história de Alexandre, menino pobre que mora na periferia do Rio de Janeiro, que ao saber que tem uma segunda madrinha, por meio do seu irmão Augusto, embarca na aventura de encontrar a casa da madrinha.

$\mathrm{Na}$ casa da madrinha, as coisas existem para satisfazer os anseios de um menino pobre, privado de bens materiais, mas livre para sonhar (SANDRONI, 1987). É por meio da imaginação que Lygia Bojunga retoma o tema da viagem iniciática, personificada no Herói, que segundo Macedo (1980), tende a significar um poema épico. O Herói entra em contato com a natureza da vida e da morte. Nessa narrativa, o indivíduo/personagem tem a possibilidade de reconciliar os elementos conflitantes que o constituem, alcançando um equilíbrio que o torne consciente de si (SANDRONI, 1987).

Lygia Bojunga, assim, coloca o leitor diante da possibilidade de refletir sobre a própria existência, com linguagem leve e coloquial, porém constituída de aspectos simbólicos. $A$ Casa da Madrinha garante o direito ao devaneio, liga-se diretamente à fantasia e promove a imaginação. Seu efeito estético, ou seja, efeito de sentidos que uma obra provoca no receptor/leitor (SIRINO; FORTES, 2011), desencadeia um processo de autoconhecimento e de consciência de mundo, uma vez que, segundo Rodrigues e Moreira (2017), a literatura pode auxiliar na elaboração de vivências psíquicas e atuar na individuação do leitor.

\section{O motivo da viagem e o tema do Herói}

A concepção de Jung, em sua psicologia analítica, considera que os símbolos são a linguagem e as "pessoas" do inconsciente, que se expressa com a vida consciente por meio do sonho (FREEMAN, 2002). Os sonhos, segundo Jung (2002), servem a um propósito compensatório. Da mesma forma, a viagem empreendida por Alexandre, em busca da casa da sua madrinha, é uma forma de compensar suas necessidades, tentando, assim, suplantar as dificuldades pelas quais passa.

De acordo com Lajolo e Zilberman (2005), a viagem tem resíduos oníricos e, por mais imaginária que seja, guarda no sonho sua mais exata significação: a de realização pessoal. A busca por essa realização se materializa no momento em que Alexandre dá vazão ao seu imaginário, o que exige o "abandono" da vida real, pois o caminho a ser seguido mostrase compensatório ao que vive no cotidiano limitador. Tem-se, aí, o prenúncio da individuação de Alexandre.

Fundamental para a compreensão da psicologia junguiana é o conceito de individuação, que designa um processo lento e gradual de crescimento psíquico. É a busca pela realização do si-mesmo (self). A individuação é gerada por uma tendência reguladora inconsciente, o self, descrita como a totalidade absoluta da psique (VON FRANZ, 2002). Segundo a autora, diferente da personalidade consciente, o self configura-se como fator de orientação íntima, que provoca o desenvolvimento e amadurecimento psicológico e só pode 
ser apreendido por meio da investigação dos sonhos de cada um.

Outro constructo importante da psicologia junguiana são os arquétipos, que constituem o inconsciente coletivo, são tipos arcaicos, primordiais, que indicam a existência de determinadas formas na psique, presentes em todo o tempo e em todo lugar. Trata-se de um conjunto definido de caracteres arcaicos, que, em forma e significado, referem-se a motivos mitológicos, surgindo em forma pura nos contos de fadas, nos mitos, nas lendas e no folclore. A figura do Herói é um desses motivos mais conhecidos (JUNG, 2014).

Sendo o resultado de uma experiência que foi repetida ao longo de várias gerações, um arquétipo também pode ser compreendido como uma forma de pensamento ou de comportamento. É uma ideia abstrata das experiências humanas básicas, que são as mesmas para qualquer indivíduo, em qualquer época e lugar. Jung (2014) distingue, assim, arquétipos de imagens arquetípicas. Os primeiros representam uma ideia abstrata; já as imagens arquetípicas são a materialização, por assim dizer, dos arquétipos. O Herói, em termos abstratos, nesse sentido, é um dos arquétipos do inconsciente coletivo, simboliza a alma enfrentando as mais duras provas em busca da realização pessoal, processo denominado pela psicologia junguiana de individuação. Em A Casa da Madrinha, a imagem arquetípica do Herói é representada pelo protagonista Alexandre.

Porém, é necessário que Alexandre, o Herói, por assim dizer, assimile e interiorize psicologicamente as cinco etapas do processo de individuação: 1 - Interiorização da persona, a personalidade exterior; 2 - a Sombra; 3 - a anima; 4 - o velho sábio e 5 - o simesmo, o self. Somente a partir da assimilação das cinco etapas, o objetivo da individuação será alcançado: a realização da unicidade no indivíduo.

É importante ressaltar que Jung (2014) chama a atenção para a diferença entre individuação e individualização. O primeiro significa a realização adequada e mais completa dos atributos coletivos do ser humano, sem esquecer as peculiaridades individuais, que consideradas adequadamente serão determinantes no melhor rendimento social. E o segundo significa acentuar deliberadamente supostas peculiaridades em oposição a considerações coletivas. A meta da individuação é livrar o si-mesmo dos revestimentos falsos da persona, bem como do poder sugestivo das imagens primordiais; o homem se torna um ser único ao realizar algo exclusivamente seu, o si-mesmo, que nada tem a ver com o ser egoísta, uma forma individualista de estar no mundo.

\section{As etapas da Individuação}

Alexandre é um menino de mais ou menos sete anos, vive no contexto de uma família pobre, é o filho mais novo de cinco irmãos; ele, dois irmãos e duas irmãs moram em um "barraco" no morro de Copacabana. A mãe é lavadeira e passadeira, as irmãs são empregadas domésticas, uma foi embora e um dos irmãos adoeceu e ficou um bom tempo hospitalizado. O pai de Alexandre tem problemas com o álcool e vive caído no chão. A persona de Alexandre se desenvolve em meio a todas as privações que vive; trabalha como vendedor de sorvetes e amendoim para ajudar nas despesas de casa e fala de sua vida 
sem restrições.

Segundo Von Franz (2002), a harmonização do consciente (processo de individuação) com o núcleo psíquico (self), geralmente, inicia infligindo uma lesão à personalidade, acompanhada de um sofrimento. A autora pontua que externamente tudo pode parecer bem, mas interiormente a pessoa sofre de um tédio, de uma sensação de vazio. Nos mitos e nos contos de fada, o estágio inicial do processo de individuação (interiorização da persona) começa com um rei que ficou doente ou envelheceu.

Nesse sentido, Augusto, o único nome dos irmãos de Alexandre que aparece na obra, é o irmão com quem Alexandre mais se identifica, a grande diferença de idade entre os dois não é impedimento para que se deem bem. No processo de interiorização e assimilação da persona, é importante demarcar que é desejo de Augusto que o irmão estude e não mais venda na praia. Alexandre é um menino esperto, gosta da escola, aprende fácil e, por isso, mudou para uma turma mais adiantada. No entanto, em virtude de algumas adversidades (irmão hospitalizado, Augusto ia casar, material escolar mais caro etc.) precisa abandonar a escola e ficar só trabalhando.

Foi então que, em uma das noites, ficou sabendo por Augusto que tinha uma segunda madrinha. Em meio à história e a pedido de Alexandre, Augusto fala do mar, que dá para ver de uma das janelas da casa da madrinha. Simbolicamente, o mar pode representar a tentativa de escapar à realidade exterior. Segundo Von Franz (2002), é símbolo do inconsciente. A imagem do mar está presente nesse estágio primeiro da individuação, aliás, a interiorização da persona é iniciada, quando Alexandre é arrebatado pela partida de Augusto.

No outro dia foram perguntar pro Augusto se ele não queria trabalhar numa fábrica em São Paulo [...]. E na hora da despedida Alexandre perguntou: Você volta Augusto? [...] - É chato sem você, Augusto!! [...] - E a casa da madrinha? [...] - Quando é que você vem me buscar pra gente ir até lá? Qualquer hora dessas. [...] - Promete? - Prometo. - Então tá. - Tchau, Alexandre. - Tchau, Augusto. [...] Mas um dia choveu tanto [...] voltou pra casa tão desanimado que resolveu o seguinte: bom, se o Augusto não voltar até o verão, eu me mando mesmo sozinho lá pra casa da minha madrinha. O verão voltou [...] Alexandre foi vender sorvete na areia outra vez. la andando com o mar do lado [...]. Como antes, como no tempo do Augusto. Só que o verão acabou e o Augusto não voltou. Então, quando foi num domingo, Alexandre resolveu que a caixa de sorvete ia servir de mala, e se mandou mesmo sozinho lá pra casa da madrinha (BOJUNGA, 2015, p. 8591).

A espera de Alexandre para a chegada do verão, a fim de poder começar sua busca, pode simbolizar a mudança, que por sua vez representa a conclusão da interiorização da persona. Outro elemento importante é a imagem do cavalo preto, no qual Alexandre viaja montado, antes de encontrar o Pavão (personagem símbolo da sombra). O cavalo preto representa os impulsos instintivos, incontroláveis que as pessoas tentam esconder, mas que podem emergir do inconsciente (CHEVALIER; GHEERBRANT, 2018). É o início da segunda fase do processo de individuação, na qual o Herói encontra e começa a interiorizar 
a sombra.

Observa-se que por meio da imaginação é possível entrar em conexão com aspectos da personalidade, que por diversos motivos as pessoas evitam o contato. Von Franz (2002) explica que Jung denominou "realização da sombra". O termo sombra foi utilizado por ele para este aspecto inconsciente porque, geralmente, aparece personificada em nossos sonhos. A sombra representa qualidades e atributos desconhecidos ou pouco conhecidos do ego. São aspectos do âmbito pessoal, que podem se tornar conscientes (VON FRANZ, 2002).

É importante esclarecer, conforme a autora acima pontua, que a sombra não diz respeito a um aspecto negativo da personalidade inconsciente. Dessa forma, qualquer coisa que o ego desconheça, mistura-se à sombra, inclusive nobres e valiosos atributos. $O$ indivíduo tanto é impelido a dar livre curso ao lado negativo de sua natureza, quanto reprimido a desenvolver o que há de melhor nela.

No meio do caminho, assim, tomado por uma atmosfera onírica, o Herói, Alexandre, conhece o Pavão, personagem que simboliza a personificação de sua sombra, mas não em um aspecto negativo, mas positivo. O Pavão teve seu pensamento "costurado", "filtrado", tal como Alexandre foi impedido de estudar, mesmo sendo bom aluno. O Pavão é a personificação de um valioso atributo de Alexandre (era esperto, ia bem na escola, mas precisou parar de estudar para trabalhar e ajudar em casa). Às vezes, inadvertidamente, funcionava como a "torneirinha" do filtro que controlava seu pensamento e se abria deixando-o livre para dar curso aos seus pensamentos.

Tive que viajar montado num cavalo preto. Foi legal. Só de noite é que foi ruim: cavalo dorme bem em pé, mas gente dorme mal montada [...] Parou, olhou a mata ali do lado, viu um toco bom pra sentar e sentou. E uns cinco minutos depois o nevoeiro chegou. Era um nevoeiro maroto, que adorava meter medo. De longe ele viu Alexandre sentado e veio vindo por trás sem fazer barulho nenhum [...] O nevoeiro rodeou Alexandre [...] Alexandre [...] Esperou. Esperou. Experimentou andar. - Ui. - Desculpa o esbarrão, não to enxergando nada. - Quem tai? - Alexandre. E aí? - O Pavão. Foi assim que os dois se encontraram (BOJUNGA, 2015, p. 25-27).

E então levaram o Pavão pra uma escola [...] que era uma escola feita de propósito pra atrasar o pensamento dos alunos. A escola pra onde levaram o Pavão se chamava Osarta do Pensamento [...] Mas quem estava interessado no assunto percebia logo: era só ler Osarta de trás pra frente. A Osarta tinha três cursos: o Curso Papo, o Curso Linha e o Curso Filtro (BOJUNGA, 2015, p. 36-37).

Assimilada a segunda etapa da individuação, a terceira etapa do processo é a identificação e aceitação do arquétipo do inconsciente coletivo, anima. O homem apresenta em sua psique tendências psicológicas masculinas e femininas, denominadas pela psicologia analítica de animus e anima. A primeira tendência refere-se à personificação masculina do inconsciente na mulher, já a segunda tendência diz respeito ao elemento feminino da psique masculina (VON FRANZ, 2002). Segundo Bachelard (2005), ao se 
reportar a Jung, o inconsciente traz aspectos de androginidade. Em outras palavras, o psiquismo humano é, em sua primitividade, andrógino.

Para a análise da obra em tela, interessa explorar o arquétipo anima, pois a jornada empreendida pelo protagonista de $A$ Casa da Madrinha toma o aspecto da integração de animus com anima. Esta, muitas vezes, é personificada na figura de uma feiticeira ou uma sacerdotisa, ligada às forças ocultas das trevas e do mundo dos espíritos - o inconsciente (VON FRANZ, 2002).

Em termos individuais, o caráter da anima de um homem é, geralmente, determinado pela mãe. E como a sombra, a anima apresenta dois aspectos, o benévolo e o maléfico. $A$ influência negativa da mãe, por exemplo, reverbera uma anima irritada, insegura, depressiva etc. Mas a anima também pode se manifestar positivamente (mediadora entre o ego e o self), quando o homem considera os sentimentos, os humores, as fantasias e experiências trazidas por sua anima ou quando os desdobra de alguma forma na literatura, pintura, escultura, música ou dança (VON FRANZ, 2002).

No caso da obra A Casa da Madrinha, Lygia Bojunga (2015) coloca o leitor diante do que Bachelard (2005) chama de leitura em anima, uma vez que o devaneio das imagens pertencem à anima, se constituindo na essência do feminino. Diante disso, a manifestação desse arquétipo na experiência de Alexandre desponta no recurso da metalinguagem dentro da narrativa. Alexandre conta muitas histórias ao longo de sua jornada (a história do Pavão, da Gata da Capa, do seu Joca, do João das mil e uma namoradas). Além disso, tem-se Augusto, que trabalha a linguagem simbólica, quando conta histórias para Alexandre, possibilitando a ressignificação dos conflitos pelo protagonista, que pode vivenciá-los por via do imaginário. Este jogo simbólico sugere a possibilidade de amadurecimento psicológico do personagem, desvenda a atividade imagética de Alexandre e mostra que, a partir da recriação da realidade, ele age de forma compensatória.

- Ah, o Augusto é legal. Eu gosto um bocado dele. Pois é, Alexandre e Augusto gostavam um bocado um do outro; tinha uma diferença grande de idade entre os dois, mas eles nem ligavam pra isso. Dormiam no mesmo canto. E se de noite Alexandre custava a dormir, Augusto ficava inventando história pra ele. Se tinha coisa que Augusto gostava era de inventar histórias; Alexandre adora escutar; às vezes ficavam inventando e ouvindo até o galo cantar (BOJUNGA, 2015, p. 59).

Ressalta-se que a anima apresenta quatro estágios no seu desenvolvimento. 0 primeiro é personificado na figura de Eva, que simboliza o relacionamento instintivo; o segundo, na figura de Helena, de Fausto, representa um nível romântico e estético, mas ainda com elementos sexuais; o terceiro, na figura da Virgem Maria, aponta para o amor que é elevado à grandeza da devoção espiritual e o quarto estágio, que pode ser personificado na figura da deusa grega da sabedoria Atenas, simboliza a sabedoria que transcende a pureza e a santidade (VON FRANZ, 2002). Nessa perspectiva, o primeiro estágio da anima se personifica na garota do Leme, descrita por Alexandre, ao falar da primeira vez que viu o Pavão. Alexandre alude a esse estágio sem desassossegos grandes. 
Eu fiquei bobo. Já tinha visto muita coisa bonita. Lá da minha casa a gente tem uma vista espetacular; no Leme tem uma garota que vai sempre à praia com o cabelo amarrado assim e que é um troço da gente olhar [...] (BOJUNGA, 2015, p. 30).

O segundo estágio é representado por Vera (personagem que acompanha Alexandre em sua jornada, junto com o Pavão). No entanto, chama-se atenção para outra personagem, a Gata da Capa, por quem o Pavão de apaixona. Nesse sentido, pode-se dizer que a Gata da Capa configura, ao mesmo tempo, um aspecto da sombra de Alexandre e também a personificação, junto com Vera, do segundo estágio de sua anima.

Vera vinha vindo [...] Todo dia ela passava ali na estrada, indo e vindo da
escola, via sempre a mesma gente, nunca tinha visto Alexandre, o jeito dele
era tão diferente [...] Fez outra festinha nela ("tão gostoso fazer festinha na
Vera"): - E olha, eu entendo também que é melhor ir embora de uma vez,
não é? [...] ficaram sem dizer mais nada. Só vendo os riscos no chão. O
Pavão suspirou tremidinho. De repente, Alexandre e Vera se olharam. E aí
Alexandre resolveu ir embora de uma vez e pronto. Mas quando foi dizer
tchau, saiu uma pergunta que ele nem estava esperando nem nada: -
Vamos andar a cavalo? (BOJUNGA, 2015, p. 10-13 e 132-133).
A Gata da Capa andava sempre enfiada numa capa de chuva abotoada até
o pescoço e meio que arrastando no chão [...] vivia procurando um lugar pra
se esconder ainda melhor do que a capa. Até que um dia encontrou o porão
da casa pra onde o Pavão tinha ido [...] ele ficou louco pra saber que gata
era aquela que todo dia sumia no porão [...] ela jogou o capuz pra trás [...] O
Pavão suspirou fundo [...] E lá dentro do peito uma sensação gostosa, que
ele nunca tinha sentido antes, crescendo [...] até que lá pelas tantas ele não
aguentou mais e desabafou: - Ai! Tô amarrado em você (BOJUNGA, 2015,
p. 114-119).

O processo de assimilação da anima continua, de modo que a professora de Alexandre aparece na narrativa como a personificação do terceiro estágio de sua anima. A professora era diferente, nunca estava sozinha, pois dava aula sempre com uma maleta.

A Professora era gorducha; a maleta também. A Professora era jovem, a maleta era velha [...] A Professora gostava de ver a classe contente [...] dias depois, choveu muito. Chuva grossa [...] Quase ninguém foi à escola. Mas Alexandre foi [...] Lá pelas tantas a Professora chegou. Mas chegou sem a maleta. E com um jeito diferente [...] - Cadê a maleta? A Professora olhou pra ele sem saber muito bem o que dizia [...] - Perdi. Ele se apavorou [...] E aí ele não perguntou mais nada. Ela também não falou mais. Até que a campainha tocou e a aula acabou (BOJUNGA, 2015, p. 61-67).

O quarto estágio da anima simboliza a sabedoria que transcende a pureza e a santidade. Assim, a Casa é o símbolo desse quarto estágio. Ainda que não apareça como personagem, a casa aparece como importante elemento para a integração do self de Alexandre. Ao chegar à casa da madrinha, o Herói está próximo de integrar-se como indivíduo. 
Lá na frente tinha um morro pequeno. Redondo e cheio de flor [...] E tinha também um caminho que ia subindo e virando no meio daquele mundo de flor [...] bem em cima do morro, meio tapada de flor, tinha uma casa bem branca, com uma janela de cada lado, e mais uma porta azul. Alexandre meio que ria, meio que se engasgava com tanta alegria [...] (BOJUNGA, 2015, p. 144-145).

A casa simboliza a imagem de uma intimidade repousante, seja como templo, palácio ou cabana, a casa é compreendida como a construção de si. Ao entrar na casa, Alexandre entra em contato com um nível de inconsciência mais elevado (DURAND, 2002), em que a casa da madrinha alcança o status do ser interior; seus andares, porão e sótão simbolizam diversos estados de alma. A psicanálise reconhece nos sonhos de casa diferenças de significação, de acordo com os elementos representados, que correspondem a diversos níveis da psique (BACHELARD, 2005).

O porão, nesse sentido, é elemento de simbolização fundamental, liga-se ao perigo de perder-se a si mesmo. É o espaço obscuro da casa, que participa das potências subterrâneas (BACHELARD, 2005). A casa, portanto, deve ser considerada, ao mesmo tempo, em sua unidade e complexidade.

Eles ficaram parados na porta escutando o batuque, Alexandre olhava e olhava, e quase não acreditava. Estava tudo lá [...] O armário que dava roupa. O outro que dava comida. A portinha que descia pro porão (BOJUNGA, 2015, p. 146-147).

Lá embaixo tinha móvel velho, bagulho, uma cesta grande [...] - Olha, tua encomenda tá aqui. Era o baú das fantasias [...] Espalharam tudo quanto é fantasia no chão; cada um se enfiou numa; brincaram de pirata, de rei [...] foi uma correria incrível pela casa (BOJUNGA, 2015, p. 151-152).

O baú é elemento análogo ao cofre e, portanto, encerra dois princípios básicos. $\mathrm{O}$ primeiro é que nele se deposita um tesouro material ou espiritual; o segundo é que a abertura do baú poderá equivaler a uma revelação (CHEVALIER; GHEERBRANT, 2018). Quanto às fantasias, estas simbolizam os arquétipos do inconsciente coletivo. Chama-se atenção também para outro objeto encontrado no porão, a maleta da professora.

Alexandre entrou devagarinho, espiou atrás da porta. Riu. A maleta da professora estava lá mesmo. Gorducha. Com o desenho do garoto e da garota de mãos dadas. Só que tinha uma poeirinha nela toda. Vera perguntou: - Fica chato a gente espiar dentro? - De jeito nenhum [...] Abriram a maleta (BOJUNGA, 2015, p. 147).

De acordo com a psicologia junguiana, o inconsciente coletivo conforma esquemas pré-simbólicos fundamentais para a conceitualização e vivência do grupo. A esses esquemas dá-se o nome de arquétipos. Assim, igualmente ao baú e às fantasias, a maleta assegura a não desintegração do ego de Alexandre que está, aos poucos, ajustando o seu self. De acordo com Von Franz (2002), quando o indivíduo luta séria e longamente com sua anima, de modo a se identificar em totalidade com ela, o inconsciente modifica o caráter 
dominante e aparece em nova forma simbólica, representada pelo self, o núcleo central da psique.

Nos sonhos do homem, este núcleo se manifesta como um iniciador masculino, um guardião, um Velho Sábio, quarto estágio do processo de individuação. Nesse sentido, a assimilação da anima se realiza no momento em que, no meio do almoço, a campainha da casa toca e a porta se abre para Augusto entrar. Augusto é a figura simbólica do Velho Sábio.

Triiiiiiiiiiiiim. Um olhou pro outro, o outro olhou pra Alexandre, e Alexandre então foi até a porta e abriu. Um pedacinho só [...] Ficou olhando, nem podendo acreditar. E aí a porta azul abriu toda pra deixar o Augusto passar (BOJUNGA, 2015, p. 154).

Assim, o processo de individuação de Alexandre se aprofunda e se aproxima da integração no reencontro com Augusto. Em meio a berros, abraços, falatório e após empreender aventura na floresta, o quarto estágio do processo é assimilado por Alexandre no momento em que a metalinguagem na narrativa é retomada e Augusto, a pedido do irmão, começa a contar história.

- Conta história pra gente, Augusto, conta. Augusto deitou no tapete; a turma deitou em volta dele; o Ah enfiou a cara pela janela; até a cadeira de braço se espichou toda pra escutar mais gostoso. E Augusto contou cada história boa mesmo. Mal acabava uma, já pediam: mais! e ele inventava outra. Inventou até todo mundo ir dormir. $\mathrm{E}$ aí virou pro lado e dormiu também. A casa da madrinha ficou em silêncio (BOJUNGA, 2015, p. 156).

Segundo Silva (2013), Alexandre e Augusto se assemelham à personagem Sherazade. Os irmãos usam as histórias como forma de sobrevivência, quando, antes de dormir, recriam suas fantasias para trabalhar a dureza do cotidiano, compartilhar seus medos e evitar a morte de seus sonhos.

A partir desse momento, o ego de Alexandre começa a ser incorporado ao self; é a integração do si mesmo, quinta e última etapa do processo de individuação. Diante disso, observa-se que o processo de individuação do protagonista da obra A Casa da Madrinha se articula à união com a madrinha. Esta é a maior conotação simbólica da individuação de Alexandre. Ela não se corporifica em uma personagem, mas aparece como entidade. A madrinha, associada à fada, simboliza a capacidade mágica da imaginação (CHEVALIER; GHEERBRANT, 2018) de Alexandre. E como a fada descrita por Mendes (2000), a madrinha, na obra de Lygia Bojunga (2015), representa a imagem arquetípica da Grande Mãe. Com efeito, a individuação de Alexandre se completa com a integração do seu duplo: ego e self, consciente e inconsciente, simbolizada na sua união com a madrinha, situada, assim como as fadas, entre o processo de adaptação ao real e da aceitação de si, com suas limitações pessoais (CHEVALIER; GHEERBRANT, 2018).

Dois elementos são fundamentais e dão substância ao simbolismo da madrinha: a flor e a chave. A flor é o símbolo do amor e da harmonia que caracterizam a natureza primordial, 
associa-se ao simbolismo da infância e, sobremaneira, ao do estado edênico (CHEVALIER; GHEERBRANT, 2018). Veja-se que Alexandre é uma criança da periferia, oprimida pela exclusão social, vítima do trabalho infantil, mas ao encontrar a casa da madrinha, experiencia o êxtase de ter encontrado, de certo modo, o refúgio/paraíso para as suas experiências adversas.

De acordo com Silva (2013), Alexandre lança mão da imaginação e recria a realidade opressora, na qual vive e na experiência simbólica encontra refúgio para lidar com seus medos, angústias e evitar o aniquilamento de seus sonhos. A autora ainda acrescenta que o imaginário infantil atua como recurso cognitivo atenuante das angústias.

[...] o Ah foi volteando o morro na calma, um cheiro tão forte de flor que os quatro ficaram até meio tontos. - Olha a flor amarela no peito da porta azul! [...] Vera cochichou pra Alexandre [...] - Vê se a chave ta mesmo guardada no fundo da flor (BOJUNGA, 2015, p. 146).

Para Chevalier e Gheerbrant (2018), a flor apresenta-se como figura-arquétipo da alma, centro espiritual. Nesse sentido, seu simbolismo se explica conforme suas cores, que revelam a orientação de tendências psíquicas. A flor que guarda a chave na casa da madrinha é amarela, revelando um simbolismo solar. Em alguns mitos, o sol era considerado o centro regulador das forças sobrenaturais (CHEVALIER; GHEERBRANT, 2018). A flor, assim, no processo de individuação de Alexandre, pode representar o self, organizador ou fonte de imagens oníricas. A chave, por sua vez, confirma a integração do si-mesmo de Alexandre. Antes de sua jornada, quando Augusto conta a Alexandre sobre a casa da madrinha, a chave já é revelada em seu simbolismo.

- Mas então [...] Escuta, sempre que eu tô com medo do escuro, de ficar sozinho, de trabalhar, de uma porção de coisas, você diz que o medo ta ganhando de mim, não diz? - Digo. - E quando um dia eu te perguntei quando é que eu ia ganhar dele você disse que era quando eu tivesse a chave da casa no bolso. Agora você ta dizendo que a chave é minha, então ta na hora de eu começar a ganhar do medo, não ta não? (BOJUNGA, 2015, p. 73).

Alexandre, ao retornar da casa da madrinha, na conclusão do seu processo de individuação, traz consigo apenas dois objetos dentro da maleta de ferramentas: a chave e a flor. Em outras palavras, está preparado para enfrentar seus medos e dificuldades de maneira consciente e, psicologicamente, integrado.

- Abriu a caixa pra pegar o lápis: - Ué. - Que é? Alexandre ficou olhando pra dentro da caixa. E aí riu de contente: - Olha a flor amarela que enfeitava o peito da porta azul. Como é que ela veio parar na minha mala? Foi você que botou ela aqui? [...] Alexandre enfiou a mão na flor pra pegar a chave da casa [...] pegou a chave e guardou no bolso; não vou ter mais problema nenhum. Lembra do que o Augusto falou? [...] Alexandre pendurou a mala no ombro e foi andando; o Pavão emparelhou com ele. Foram sumindo e sumindo; e aí sumiram de vez numa dobra do caminho (BOJUNGA, 2015, p. 167-169). 
Na obra de Lygia Bojunga (2015), A Casa da Madrinha, o jogo imaginativo tanto no nível estético, quanto do ponto de vista da psicologia do protagonista, permitiu realização de uma leitura/análise simbólica, a partir da Psicologia Analítica de Jung (1875-1961). Segundo Silva (2013), a literatura de Lygia Bojunga traz uma abordagem crítica da realidade social, bem como uma reflexão sobre a importância da imaginação, não como fator de alienação do real, mas como processo fundamental de transformação e mobilização da vida. Com efeito, destaca-se que Alexandre, na experiência de seu processo de individuação, foi capaz de ressignificar seus espaços de vida exterior e interior.

\section{Conclusão}

A análise aqui realizada demonstrou o alcance do objetivo proposto, que foi analisar a obra $A$ Casa da Madrinha, a partir de uma leitura junguiana, desvelando a jornada de Alexandre, personagem central, como símbolo do processo de individuação do indivíduo. Para tanto, a Psicologia Analítica de Carl Gustav Jung (1875-1961) foi utilizada como instrumento de revelação do simbólico, do mitológico, da obra de Lygia Bojunga (2015).

A maneira como a escritora estruturou a narrativa em $A$ casa da Madrinha possibilita dois níveis de apreensão: um, objetivo, quando lança mão do tema da problemática social; e outro, subjetivo, por meio da metáfora. A busca pela integração do ser se faz presente nesta obra, por meio da história de Alexandre, um menino da periferia do Rio de Janeiro, que enfrenta as dificuldades de uma vida de privações, marcada pelo trabalho infantil e resolve ir ao encontro da casa da madrinha para viver a sua jornada psicológica, o processo de individuação.

O universo psicológico do personagem foi projetado no espaço de fantasia da obra. E o papel funcional desse espaço de fantasia foi evidenciado pela teoria do processo de individuação, desenvolvida por Carl Gustav Jung (1875-1961), em que os elementos constitutivos da narrativa simbolizam aspectos da vida psicológica inconsciente, tais como: arquétipo, anima, sombra, self.

Diante de tais considerações, observa-se que a construção narrativa de Lygia Bojunga (2015) oferece ao leitor a possibilidade do devaneio. A obra A casa da Madrinha promove um efeito estético que, relacionado à estética da recepção, diz respeito ao efeito de sentidos que uma obra provoca no receptor/leitor (SIRINO; FORTES, 2011). Portanto, a partir do recurso metafórico, pode-se dizer que a jornada de Alexandre tem ressonância na subjetividade do leitor, de modo que a realidade, assim, seja suspensa para dar lugar à fantasia, à imaginação.

\section{Referências}

BACHELARD, Gaston. A poética do espaço. São Paulo: Martins Fontes, 2005.

BOJUNGA, Lygia. A Casa da Madrinha. Rio de Janeiro: Casa Lygia Bojunga, 2015. 
CHEVALIER, Jean; GHEERBRANT, Alain. Dicionário de símbolos: mitos, sonhos, costumes, gestos, formas, cores, números. Rio de Janeiro: José Olympio, 2018.

DURAND, Gilbert. As estruturas antropológicas do imaginário. São Paulo: Martins Fontes, 2002.

FREEMAN, John. Introdução. In: JUNG, Carl G. (Ed.). O homem e seus símbolos. Rio de Janeiro: Nova Fronteira, 2002, p. 9-15.

JUNG, Carl Gustav. Chegando ao inconsciente. In: JUNG, Carl G. (Ed.). O homem e seus símbolos. Rio de Janeiro: Nova Fronteira, 2002, p. 19-103.

JUNG, Carl Gustav. Os arquétipos e o inconsciente coletivo. Petrópolis: Vozes, 2014.

LAJOLO, Marisa; ZILBERMAN, Regina. Literatura infantil brasileira: história e histórias. São Paulo: Ática, 2005.

MACEDO, Helder. Camões e a viagem iniciática. Lisboa: Moraes Editora, 1980.

MENDES, Mariza. Em busca dos contos perdidos: o significado das funções femininas nos contos de Perrault. São Paulo: Editora UNESP, 2000.

PIRES, Carlos; GOMBOEFF, Ana Lúcia Madsen. Infância e sociedade em A Casa da Madrinha, de Lygia Bojunga Nunes. Veras, v. 2, n. 2, p. 293-295, 2012.

RODRIGUES, Isabela Paixão; MOREIRA, Fernanda Gonçalves. Elaboração das vivências psíquicas: o papel da literatura. Revista da Sociedade Brasileira de Psicologia Analítica, v. 35, n. 1, p. 61-67, 2017.

SANDRONI, Laura. De Lobato a Bojunga: as reinações renovadas. Rio de Janeiro: Agir, 1987.

SILVA, Luciana Aparecida. O jogo do imaginário e a morte social e $A$ Casa da Madrinha. Anais do CENA, v. 1, n. 1, p. 189-194, 2013.

SIRINO, Salete Paulina Machado; FORTES, Rita das Graças Felix. Jauss e Iser: efeitos estéticos provocados pela leitura de Conversa de Bois e Campo Geral, de João Guimarães Rosa. Revista Científica/FAP, v. 7, p. 209-228, 2011.

VON FRANZ, Marie Louise. O Processo de Individuação. In: JUNG, Carl G. (Ed.). O homem e seus símbolos. Rio de Janeiro: Nova Fronteira, 2002, p. 158-229.

\section{NOTAS DE AUTORIA}

Dalízia Amaral Cruz (liz.amaralcruz@gmail.com) é licenciada em Letras/habilitação em língua portuguesa e Psicóloga pela Universidade Federal do Pará (UFPA), Doutora em Psicologia (Teoria e Pesquisa do Comportamento) pela UFPA, Especialista em Psicopedagogia Institucional pela Universidade da Amazônia (UNAMA) e Estagiária de Pós-doutorado em Psicologia (Teoria e Pesquisa do Comportamento) na UFPA.

Marluce Cristina Araújo Silva (mardeluz26@gmail.com) é licenciada em Teatro pela Universidade Federal do Pará (UFPA), Técnica em Artes Dramáticas pela Escola Técnica Estadual de Teatro Martins Pena - Rio de Janeiro, Especialista em A Arte de Contar Histórias pela Faculdade Conhecimento e Ciência (FCC) e Mestranda em Artes na UFPA. 
Elson Ferreira Costa (elsonfcosta@gmail.com) é Terapeuta Ocupacional pela Universidade Estadual do Pará (UEPA), Doutor e Mestre em Teoria e Pesquisa do Comportamento pela Universidade Federal do Pará (UFPA), Especialista em Saúde da Criança e do Adolescente pela Faculdade UniBF e Docente do Curso de Terapia Ocupacional da Universidade do Estado do Pará (UEPA).

\section{Como citar esse artigo de acordo com as normas da ABNT}

CRUZ, Dalízia Amaral; SILVA, Marluce Cristina Araújo; COSTA, Elson Ferreira. A Casa da Madrinha: o processo de individuação na obra de Lygia Bojunga. Anuário de Literatura, Florianópolis, v. 26, p. 01-14, 2021.

\section{Contribuição de autoria}

Dalízia Amaral Cruz: participou da concepção, coleta e análise de dados, elaboração e redação final do manuscrito e discussão dos resultados.

Marluce Cristina Araújo Silva: participou da concepção, coleta de dados, elaboração e redação do manuscrito.

Elson Ferreira Costa: participou da concepção, elaboração e redação do manuscrito e discussão dos resultados.

\section{Financiamento}

Não se aplica.

\section{Consentimento de uso de imagem}

Não se aplica.

\section{Aprovação de comitê de ética em pesquisa}

Não se aplica.

\section{Conflito de interesses}

Não se aplica.

\section{Licença de uso}

Os/as autores/as cedem à Revista Anuário de Literatura os direitos exclusivos de primeira publicação, com o trabalho simultaneamente licenciado sob a Licença Creative Commons Attribution (CC BY) 4.0 International. Estra licença permite que terceiros remixem, adaptem e criem a partir do trabalho publicado, atribuindo o devido crédito de autoria e publicação inicial neste periódico. Os autores têm autorização para assumir contratos adicionais separadamente, para distribuição não exclusiva da versão do trabalho publicada neste periódico (ex.: publicar em repositório institucional, em site pessoal, publicar uma tradução, ou como capítulo de livro), com reconhecimento de autoria e publicação inicial neste periódico.

\section{Publisher}

Universidade Federal de Santa Catarina. Programa de Pós-graduação em Literatura. Publicação no Portal de Periódicos UFSC. As ideias expressadas neste artigo são de responsabilidade de seus/suas autores/as, não representando, necessariamente, a opinião dos/as editores/as ou da universidade.

\section{Histórico}

Recebido em: 15/06/2020

Aprovado em: 04/09/2020

Publicado em: 23/04/2021 